\title{
Broadening the World of Knowledge: The Effects of Travel on the Transfer of Linguistic Data between Asia and Europe
}

\section{Abstract}

This paper provides an examination of the effects of contact between Europe and Asia in the early modern period, especially with regard to the exchange of linguistic data and ideas. The contact induced by transcontinental travel - with various motives, including missionary work and increasing colonial expansion - added fuel to the intellectual study of language. Both Europe and Asia gained access to new languages and approaches to language, which enabled an exchange of linguistic data and methodologies, which can now be seen as one of the origins of the development of modern linguistics. In order to illustrate the main developments within modern linguistics, earlier systems are briefly addressed along with some of the roots of their transformation or displacement. Latin treatises, including De antiquitate et affinitate linguae Zendicae, Samscrdamicae et Germanicae dissertatio and De Latini sermonis origine et cum orientalibus linguis connexione dissertatio, serve as examples of the earliest development toward comparative linguistic studies in the West. These texts, written by the Carmelite Ivan Filip Vesdin (alias Paulinus a Sancto Bartholomeo; 1748-1806) are some of the earliest Western texts offering a comparative description of the Sanskrit language. Although basically referring to the history of linguistics, this article provides an insight into the transfer of ideas and concepts between cultures and peoples of these macro-regions of human civilization.

Keywords: Chinese linguistics, history of linguistics, Indian linguistics, intellectual exchange, Japanese linguistics 


\section{Introduction}

Although much has been written about the history of contacts between Asia and Europe - often characterized in terms of colonial and postcolonial outcomes ${ }^{1]}-$ I shall leave this history aside and focus on those connections that led to the development of new ideas and approaches to language description, to the study of language, and to linguistic thought. To fulfil this task, I am going to present several important points in the course of exchange between West-European and some Asian cultures - Chinese, Japanese, and Indian. Only certain aspects of the topic will be addressed due to lack of space.

The contact induced by the traveling activity - with various motives, including missionary work and increasing European expansion - added fuel to changes within the intellectual field of linguistics. Both Europe and Asia gained access to new languages and approaches to language, which enabled an exchange of linguistic data and methodologies, which can be now seen as one of the origins of the development of modern linguistics. Today, this scientific field is shared by linguists throughout the world, and is considered a global science.

\section{The Role of Missionaries in the Intellectual Exchange}

Most of the information about Asian territories was first brought to Europe by travelers, especially those who traveled and transferred their experiences into written forms, texts that were afterwards discussed, and occasionally dissected and incorporated into later writings. In Eurasian history there were a number of particularly important connections between Asian and European countries, including the crucially important Silk road - a set of old routes that served as a means of circulating goods and wares in both directions - that had been established in prehistoric times. Although many more routes were later established, due to the expansion of certain states as well as for economic reasons, it was not before the early modern period that significant linguistic knowledge from the Far East began to circulate among the European elite, including Christian missionaries.

Christian missionaries such as Franciscans, Augustans, Dominicans, Carmelites, Jesuits etc. had an important role in this process, as their task of spreading a new creed included both learning a 
foreign language and teaching an indigenous people a European language which they spoke while trying to establish a Western worldview among their students. In particular, the Jesuits - a Christian Catholic order - were very active in spreading the Christian faith outside Europe after the mid-16th century - particularly in China, as well as in Japan and India, but their activity was very strong in the Americas, too. They are very much credited for writing some of the earliest descriptions and grammars of various non-European languages; Vietnamese orthography, for example, was established by the Jesuit Alexandre de Rhodes, the author of a trilingual Vietnamese-Portuguese-Latin dictionary, in 1651. Such missionary schools became the starting point for the spread of Western influence, for example, through the traditional methodology of describing language. They taught Latin to Christian converts in their missions, so these people were the first to gain insight into a foreign, Christian, and European worldview. The Jesuit pedagogical manual, Ratio studiorum (1599), strongly orientated toward humanistic studies, was used while educating indigenous peoples, all of which helped to introduce Western concepts to the Far East and South Asia. In addition, Latin texts served as sources for approximately one thousand Chinese works, some of which are translations from Latin, but many of which incorporate Latin into Chinese-language works (Golvers 558).

It was not uncommon that those Jesuits who had acquired a solid grounding in traditional cultures wrote studies intended for distribution among Jesuit readers in Europe, mainly in Latin, with the purpose of helping to prepare future mission candidates and, indirectly, of educating other scholars about the East (cf. Golvers 565). More important, still, was the fact that many of these Jesuit reports included information about the lands in which they worked, including cultural, scientific and various anthropological data. Many of their letters, treatises and reports were published afterwards or at least served as a source of information to the limited circle that had access to it. So, while the foundation of mission stations could be regarded, in a way, as the establishment of religious strongholds, many had an important role in disseminating data about Asian cultures to Europe. Unlike the early missionaries, who wrote the first accounts of various aspects of Asian cultures, and which have now great philological, historical, or linguistic value, the majority of scholars who wrote in all kinds of ways about Asian cultures never actually visited the place, including the German philosopher Gottfried Wilhelm Leibniz (1646-1716), who had never traveled to China, but 
propagated the works of the missionaries and, among other things, made important advances in the field of Chinese studies in Europe (cf. Lach 436-55). In much the same way, many premodern Asian scholars never set foot on European ground, and it was rather that European scholarship was brought to them. Nevertheless, the circulation of printed books and manuscripts secured a flow of information between the intellectual classes of the two continents and beyond.

\section{From Catholic Missionaries to Modern Linguistics in Japan}

The earliest accounts of the Japanese language reached Europe as short notes from Christian missionaries, along with other cultural data and information on the missions' progress, the first of which had been established in 1549, with the Portuguese Jesuit Francis Xavier at its head. At first the mission thrived and many Japanese converts adopted Portuguese names (as Christians) and received education in the Latin language in order to become missionaries. The best students who were sent to Rome in 1582 returned eight years later bringing a printing press, on which, among other publications, a book on Latin grammar and a Latin dictionary were printed, as well as a Japanese translation of Aesop's fables. However, Christians were soon regarded as foreign agents, and under the Tokugawa government they were outlawed and fiercely persecuted. In turn, the Jesuits sent the printing press to Macau in 1614, where they continued to produce materials needed by the mission stations, although all Latin books were burned around 1627 (Taida).

Nevertheless, the mission press's texts in Japan are today still used as a source for literary and linguistic study of the Japanese language, for they preserve the mediaeval pronunciation (if printed in rōmaji:2] for the use of missionaries learning Japanese) and can be also used as sources for historical vocabulary. Such publications were scrutinized by later researchers such as Doi Tadao (1900-1995), in order "to clarify the Jesuits' systematisation of the Japanese grammar and their effort to study the language" (Fujikawa). During the period of Japanese isolation that began in 1641, contact with Europeans was maintained through the port of Nagasaki, and Japan "in this way gained access to European learning, for which it had a ravenous hunger" (Chung 225). This resulted in the translation of a Dutch grammar into Japanese in 1815. Shinto priest and scholar, Tsuramine Shigenobu, applied the language categories of Dutch to early Japanese in his Gogaku Shinsho (New Book of Language Study), published in 1833. After the initial interest in the study of 
older language forms, which were considered more interesting, the focus shifted to the modern vernacular. The first grammar of modern Japanese, which included European grammatical concepts such as the parts of speech, was Baba Tatsui's Elementary Grammar of the Japanese L anguage, printed in London in 1873 (Chung 225-26) and followed by several of a similar kind. In 1897, for example, Ōtsuki Fumihiko published A Comprehensive Grammar of Japanese, which included both early indigenous studies and Western grammar (Chung 226). Moreover, interest in Latin continued until the Japanese government opened the door to European science in the 18th century (Taida), even though the first Japanese grammar was not modeled directly upon the Latin system, but rather on that of Dutch grammar, which inherits traits of Latin models.

Grammar has been studied as an obligatory subject at Japanese schools ever since the Meiji Restoration, and modern scientific linguistics is a thriving discipline among Japanese scholars. Modern linguistics, globally speaking, is based on Western-style models, but it was strongly modified when various structures in various world languages began to be studied. Natsuko Tsujimura, in her preface to The Handbook of Japanese Linguistics, emphasizes that:

[s]ince the inception of the generative approach to linguistic research, the field of theoretical linguistics has made tremendous progress. Various theories have been proposed and developed to account for the universality of the human language faculty. At the same time and to the same end, researchers have made a remarkable contribution to this progress by investigating a wider range of languages, far beyond English and others in the Indo-European family. The field of Japanese linguistics has certainly followed this trend for the last thirty years. Japanese has become one of the most closely examined languages, and serves as a testing ground for theoretical developments in virtually all areas of linguistics. (xi).

\section{China - The Question of Linguistic Description}

The early missionaries who traveled the world, although usually very learned men, faced the difficult task of making themselves acquainted with new languages, sometimes very different from Latin and their mother tongues. Not only morphology or syntax, but sometimes very rich sound systems, such as those in Africa and the Americas, were a source of great difficulty. In Asia, there also existed greater obstacles to constructing accurate grammars, especially in the case of 
Chinese languages, which are structurally very different from Indo-European ones. They belong to the Sinitic branch of the Sino-Tibetan language family, and are highly analytical to isolative in their grammar. That is, they primarily convey relationships between words in sentences using auxiliary words, such as particles, prepositions, postpositions, modifiers, etc. For this reason, they are difficult to describe by means of traditional European grammatical concepts, which were primarily developed for the description of classical languages such as ancient Greek and Latin, which convey the roles of words in sentences by means of inflections. As it was impossible to describe and teach the Chinese language adequately using Latin grammatical terms and categories, early authors such as Verbiest in 1678 criticized it for its lack of inflection (Golvers 567). A further problem was imposed by transliteration and transcription, and representation of the tones. Even adapting Chinese words into Latin as an inflectional language was a difficulty. European treatises thus discuss the origin and nature of the Chinese script in a then fashionable context of searching for the "universal" or "original language" (Golvers 567-68).

China has a rich tradition of language description, but Chinese scholars never composed descriptive grammars and in this respect their approach differs significantly from the European grammatical tradition. Chinese language thought has been developed by many generations of scholars, with didactic and philosophical goals, and reflects the structures of a particular language, but also the fact that the language is, roughly speaking, seen through the lenses of a logographic script. Chinese philologists have produced many lexicographical, poetic and etymological works, writings on prosody, etc. Some beginners' books for language study date from the 3rd century B.C. Various lexicons, as Ěryă, for example, aim at explaining less known characters, and there are dictionaries that compare material from various dialects. One of the oldest etymological dictionaries, made by the lexicographer Xu Shen in the A.D. 2nd century, is an etymological dictionary that lists 540 radicals (graphical components of characters mostly indicating their meaning) - the system that is basically in use nowadays, too. The question of tones arose after the adoption of Buddhism as the process of translation made Chinese scholars aware of the importance and nature of the tones in their language, in contrast to Sanskrit and other languages, and Shen Yue (A.D. 441-513) authored the first major work dedicated to this topic (Chung 215). All 
these works and many more have served as a source of data for more recent research on the history of Chinese and of Chinese linguistics.

Writings of missionaries who traveled to China, as well as of those who departed for Japan and other East Asian countries, were in high demand among European readers during the second half of the early modern period. European interest in the Chinese language in the 17th century resulted in, among other things, several Latin language descriptions and a number of lexicographical works. The first Latin grammar of Chinese was Martino Martini's (1614-1661) Grammaticae linguae Sinensis, 1652/53 (Golvers 567), and Ferdinand Verbiest's (1623-1688) grammar Elementa linguae Tartaricae - they both describe the Chinese language on the basis of the categories of Latin grammar. Golvers indicates that Marino's grammar takes as a starting point the categories of Renaissance Latin grammar as set out by Johannes Despauterius (1480-1520) and Manuel Álvares (1526-1582), largely simplifying and distorting the proper character of the Chinese linguistic system (567). More comprehensive descriptions followed.

The first European-style grammar of the Chinese language was introduced to China in the 19th century, during the Qing dynasty. Chinese scholar Ma Jianzhong, who traveled to Europe and studied in Paris, published his Mashi Wentong in 1898. This is an analysis of classical Chinese, again mainly according to Latin categories. However, he kept certain traits of the traditional Chinese description - for instance, the opposition between content and function words (Chung 219) - thus creating a methodological hybrid.

\section{India and the Rise of Historical and Comparative Linguistics in the West}

The oldest comprehensively written explanation of a grammatical system in the world is the Așțādhyāyī (Eight Study-units), composed by Pāṇini in the 4th century B.C. It differs profoundly from the system developed in Europe - approximately 4000 rules explain the highly complex Sanskrit grammar in the form of aphorisms and lists of basic forms to which these rules apply. Extremely concise, this grammar consists of phonology, morphology, syntax, and semantics of the late Vedic Sanskrit language. Indian linguistic tradition predates Pānini's grammar - the author 
himself mentions in his grammar a number of earlier scholars. The Indian tradition is closely related to religious causes, so thanks to the fact that the ancient Vedic hymns, the oldest of which made the Rg Veda, needed to be preserved in their exact forms and contexts, including pronunciation, six branches of studying the Vedas had already developed by 500 B.C. Four of the six vedāniga ("limbs" of the Vedas) deal with linguistic analysis - the chandas (metrics), nirukta (etymology), śikṣā (phonetics) and vyākaraṇa (grammar). The basic motive for the investigation and explanation of the Vedic language was the fact that, as the language of those who had the sacred task of preserving the Vedas had changed with the passage of time, the Vedic language had become increasingly more difficult to understand.

The Aștādhyāyī, which remained the most influential grammar through most of Indian history, was later accompanied by a number of commentaries. Some of them are Patañjali's Mahābhāṣya (Great comments) ${ }^{[3]}$ from the 2nd century B.C. and Bhartṛhari's Mahābhāṣya from the A.D. 7th century, as well as Bhartṛhari's text Vākya-padīya (Words in a Sentence). Pāṇini's grammar held an important place throughout Indian intellectual history, and "unlike most other grammars, the Așțādhyāyī became a truly pan-Indian grammar, known to almost all persons involved in the educational process" (Aklujkar 199). Language descriptions of other Indian literary languages, such as the Prakrits and the Dravidian languages Tamil, Telugu, and Kannada, were composed on the basis of the Aștādhyāyī, but they differ from it in the technical sense and for that reason they are named non-Pāninian grammars. Persian grammar was composed in the 16th century in Sanskrit and it derives Persian from Sanskrit rules (Scharf 253).

The Pāninian grammatical system and Indian linguistic thought in general were not only a matter of interest to the European missionaries, colonial administrators, and scholars who stayed in India, but they also reached beyond the borders of the Indian subcontinent. Indeed, they produced a vast amount of scholarship and continue to be examined by Indian and Western scholars alike.$^{[4]}$ The Pāninian tradition is mirrored in certain modern descriptions of Indo-European languages. A quote from one of Velizar Sadovski's works that deal with nominal composition in a number of IndoEuropean languages gives one of the reasons:

[T]he chapters on compounding in the Indian vyākarana theory lack adequate correspondence in Graeco-Roman grammar, and therefore the Sanskrit denotations for the respective compound 
classes were adopted in Western linguistics in the 19th century also for other languages (Sadovski 352).

Thus, while in 19th-century India Western-style grammars of modern Indian languages started to appear and the usage of Sanskrit in describing language gradually began to retreat, the knowledge of Sanskrit had a major impact on Western researchers and gave rise to historical and comparative linguistics in Europe. It influenced the work of Franz Bopp, and later on, writers including Ferdinand de Saussure, Leonard Bloomfield, Roman Jakobson, and many other linguists.

\subsection{Filip Vesdin as an Example Figure in the Development of Early Linguistics}

Before the 17th century Christian missionaries were mainly interested in vernaculars, for practical reasons of sheer communication with indigenous people. There is enough evidence of manuscript grammars of various vernaculars written and used by them during the early modern period. This is, to offer one example, confirmed by a printed lette ${ }^{[5]}$ of the missionary Filip Vesdin (1748-1806), who mentions older Malayalam grammars while praising the one composed by the German Jesuit Johann Ernst Hanxleden (1681-1732), one of Vesdin's predecessors in Kerala. Hanxleden was an important figure in the history of Western study of Sanskrit as he copied, introduced and annotated several Sanskrit lexical and grammatical manuscript works, for example one of the three Amarasiṃha manuscripts (used later by Filip Vezdin), and he also commented on Sanskrit poetical works (Van Hal and Vielle 7).

Vesdin, alias Paulinus a sancto Bartholomaeo, belonged to the Christian order of the Barefoot Carmelites. He traveled to India in his late twenties and spent almost fifteen years on the Malabar coast (today's Kerala state in southern India), which resulted in the publication of a great number of scholarly works dealing with religion, mythology, languages, and linguistics. Malayalam is the local vernacular of Kerala, and Vesdin (like Hanxleden) was so well-versed in this language that he even wrote poetry in it. In the late 18th century Europe was eager to learn from travelers, as much firsthand information about faraway Asian lands was beneficial in a variety of ways. India inspired European Romanticism, among other things, and significantly influenced the scientific and literary 
life of Europe, as well as its spirituality. Some of Vesdin's works were hugely popular and were translated from Latin for the broader public. A book about his experience of India - Viaggio alle Indie Orientali, a travelogue written in Italian ${ }^{[6]}$ - was the most popular of his works.

He also authored the first printed Sanskrit grammar in Europe, the Sidharubam seu Grammatica Samscrdamica [Sidharubam or Sanskrit grammar] in 1790, following the system of Indian grammar. Fourteen years later he published another Sanskrit grammar, Vyacarana seu locupletissima Samscrdamicae linguae institutio [Vyākarana or the Most Ample Arrangement of the Sanskrit Language], which better conformed to the expected form of European traditional grammar based on the Graeco-Roman categories, and was thus judged to be more systematic. These two grammars exemplify what happened to Indian grammatical description on its way to Europe: it had to be adapted to the Western grammatical tradition. Vesdin also published in 1798 the first known methodical study on the relationship between the Indo-European languages, De antiquitate et affinitate linguae Zendicae, Samscrdamicae et Germanicae dissertatio. [Dissertation on the Antiquity and the Affinity of the Zend, Sanskrit, and German Languages]. Vesdin was acquainted, like many other scholars of the period, with the lecture given by Sir William Jones (1746-1794) in 1786, in which Jones argued that the classical languages Sanskrit, Ancient Greek, and Latin were mutually related; he propagated the idea of the existence of a protolanguage as the parent of most of the languages of Europe, south-western Asia, and northern India[?]

Vesdin pointed to the fact that even Jones's famous formulation had not influenced knowledge concerning the relationship between these languages as he had never produced any evidence to support his argument (Vesdin 18). So Vesdin did the work - in his De antiquitate he brought together various examples of the Avestan, Sanskrit, and German languages to prove their common origin, and Croatian scholar, Milka Jauk Pinhak, estimates that he had laid certain basic criteria in language comparison. According to her, he was the first to seek similarities and correspondences in words and elements of language structure and to list them as arguments for his theses on genetic relationship and common origin (Jauk Pinhak 134). Another among Vesdin's treatises on the interrelatedness of the Indo-European languages is De Latini sermonis origine et cum orientalibus connexione dissertatio [Dissertation on the Origin of the Latin Language and its Relation to Oriental Languages], from the year 1802. As was still common at that time, he worked 
within the Biblical framework. Based on linguistic comparison and his reconstruction of possible migration routes of these peoples to Greece and Italy, Vesdin added Indians to the progeny of Javan, son of Japheth (that is, to Greeks and Romans). He wrote that Greek had inherited Indian expressions and passed them on to the Latins. Working in the Biblical context had been a common trait of European linguistic thought ever since the Middle Ages, but by the 19th century it had gradually fallen out of favor. With his methodological advances toward exact scientific argumentation and the power of his insight, Vesdin was indeed a scholar on the verge of a great shift. Despite the fact that he is, in global terms, one of the lesser-known pioneers of Indology. British Sanskrit scholars had a more significant impact in this field, with which Vesdin, who worked and published in Rome, could not compete.

The 19th century was the period of rapid development of linguistics as a science in Europe, mainly based on comparative and historical study of the newly-set notion of Indo-European languages. When linguists looked more deeply into the traditional Indian grammar, great advances in the understanding of phonology and morphology followed, and not only those of Sanskrit, but also of other Indo-European languages. Many emphasize the fact that modern grammar and phonetics were based on analyses within Indian scholarship. For example, Revathi Krishnaswamy wrote in her study of the postcolonial perspective in the 19th-century language ideology that "[t]he Sanskritocentrism of comparative philology has indeed led to a vast and formidable scholarship on the Paninian grammatical tradition both in the west and in India" (Krishnaswamy 48).

\section{Broadening the World of Knowledge: European Developments}

The development of grammatical description in Europe was for a long time closely connected to the study of the Latin language - from Roman antiquity all the way to the early modern period Latin was the language of high culture and the main instrument in the spread of knowledge among the major part of the Western European cultural elite. Grammatical explanations of late Roman grammarians such as Donatus and Priscian formed the canon of teaching and study of this language and were the basis for a number of descriptions of European vernaculars which started 
to emerge during the early modern period. Practical grammars of later periods grew out of this tradition.

Another standpoint from which language was described in Europe was philosophical - from the Classical Greek period language represented a huge topic in the discussions of the stoics, Plato, Aristotle, and others - who continued to impact or interact with later ideas on language. After the period of the Humanistic movement, which posed "a serious threat to any type of philosophical grammar" (Maat 403), 17th-century Europe began to see language as the instrumentum rationis a tool of reason. A new, rationalistic view emerged and with it also an exploration of the logical structure of languages. Before the beginning of the 18th century, philosophical grammar had been already formed as a linguistic discipline per se and 18th-century philosophers searched for a universal grammar speculating about the origin of language. The interest in the historical perspective of languages thus arose and the study of differences among languages gave rise to language typology. In this atmosphere various language data reaching Europe from Asia was of great interest. To give an example, it was already Leibniz, as mentioned earlier, who demonstrated an interest in the Chinese language while attempting to develop a clavis Sinica - a "key" to a faster learning of the Chinese script and language. The clavis was one of the most widespread concepts on the Chinese language in 17th and 18th-century Europe and

was initially based on the possibility of a universal language and on Chinese as its candidate par excellence, either because it was closely related to the original primitive language - predating the post-Babelian confusion - but also through the concept of the real character, which permitted that "writing represents not mere words, but also things and ideas." (Baretto 199).

In the 19th century philosophical speculations gradually diminished and interest in a rigorously empirical investigation of language took a central place in the study of language. Linguists such as Jakob Grimm, Franz Bopp, and others, with their urge to collect significant amounts of data on languages (mainly on Sanskrit and other Indo-European languages, such as Persian) and the application of natural science methods, gave rise to comparative and historical linguistics. Not only European and Asian languages, but languages from all over the world, too, became material of 
study as language typology of the 19th century led to the systematization of languages on a nonhistorical basis.

\section{Conclusions}

Travel, as a key point in reaching the Other, has provided both sides with certain knowledge interest in languages was based on the need to communicate as the language barrier had to be crossed. Merchants and adventurers needed to communicate with ordinary people and local governments, as well as missionaries, who also had to teach local people their own languages in order to spread Christianity. Diplomacy was an important issue, as it is today, so languages had to be learned, and language descriptions and dictionaries emerged and improved with time. The missionary grammars nowadays form a special subfield of the history of linguistics. The Europeans who intensively studied indigenous people, their traditions and cultures, sometimes gained a thorough knowledge of the environments in which they were stationed. Learned travelers, such as missionaries, faced several challenges. Apart from learning local vernaculars they had to deal with high language variants, i.e., classical languages, in order to be able to study sacred and legal texts. Traditional descriptions of the languages involved were the natural starting point, but also objects of admiration. A number of scholarly descriptions which reached Europe were printed and published, which increased the Westerners' interest in and knowledge of these languages.

In the course of history, contacts between European colonial and Church authorities and Asian countries brought about numerous clashes and a struggle for power, but also involved episodes of mutual appreciation. India, China, and Japan shared, as they still do, their cultural goods with the Western world, and vice versa. They poured their religious and philosophical knowledge, sometimes also their sciences and literatures, over their cultural borders and into the Western world, thus broadening the Western knowledge of the world. Asian cultures have impacted deeply and continue to impact upon the Western worldview. In the context of the development of linguistics as a modern science, a great amount of linguistic data fueled European philosophical and practical discussions of language, while the intake of data enabled the development of new views on languages, rooted in scientific methods of European origin. Since the early 20th century 
modern linguistics has evolved into a global science, including countless views, theories, and methods, and encompassing all the languages of the world.

\section{Works Cited}

Aklujkar, Ashok. "Traditions of Language Study in South Asia." Language in South Asia, edited by Braj B. Kachru, Yamuna Kachru, and S. N. Sridhar, Cambridge University Press, 2008, pp. 189220.

Barreto, Cristiano Mahaut de Barros. "Clavis Sinica, A Short History of the Long Battle for the Chinese Writing System in the West Between the XVI and XIX Centuries." Alfa, Revista de Linguística (São José do Rio Preto), vol. 61, no. 1, 2017, pp. 197-222.

Chung, Karen Steffen. "East Asian Linguistics." The Oxford Handbook of The History of Linguistics, edited by Keith Allan, Oxford University Press, 2013, pp. 209-26.

Fujikawa, Mayu. "Studies on the Jesuit Japan Mission." Jesuit Historiography Online. Brill, March 2017, dx.doi.org/10.1163/2468-7723_jho_COM_196472. Accessed 3 March 2019.

Golvers, Noël. 2015. "Asia." The Oxford Handbook of Neo-Latin, edited by Sarah Knight and Stefan Tilg, Oxford UP, 2015, pp. 557-73.

Hertel, Ralf, and Michael Keevak, eds. Early Encounters between East Asia and Europe: Telling Failures. Routledge, 2017.

Jauk-Pinhak, Milka. "Filip Vezdin, De latini sermonis origine”. Živa antika, vol. 34, 1984, pp. 13338.

Krishnaswamy, Revathi. "Nineteenth-century Language Ideology: A Postcolonial Perspective." Interventions, vol. 7 , no. 1, 2005, pp. 43-71.

Lach, Doland F. "Leibniz and China." Journal of the History of Ideas, vol. 6, no. 4, 1945, pp. 43655.

Maat, Jaap. "General or Universal Grammar from Plato to Chomsky." The Oxford Handbook of The History of Linguistics, edited by Keith Allan, Oxford University Press, 2013, pp. 397-417. 
Sadovski, Velizar. "Dvandva, Tatpurusa and Bahuvrihi: On the Vedic Sources for the Names of the Compound Types in Panini's Grammar." Transactions of the Philological Society, vol. 100, no. 3, 2002, pp. 351-402.

Scharf, Peter M. "Linguistics in India." The Oxford Handbook of The History of Linguistics, edited by Keith Allan, Oxford University Press, 2013, pp. 227-57.

Taida, Ichiro. "The Earliest History of European Language Education in Japan, Focusing on Latin Education by Jesuit Missionaries." Classical Receptions Journal, vol. 9, no. 4, 2017, pp. 566-86.

Tsujimura, Natsuko, ed. The Handbook of Japanese Linguistics. Blackwell Publishing Ltd, 1999. Van Driem, George. Languages of the Himalayas: An Ethnolinguistic Handbook of the Greater Himalayan Region Containing an Introduction to the Symbiotic Theory of Language. Brill, 2001. Van Hal, Toon and Christophe Vielle, eds. Grammatica Grandonica: The Sanskrit Grammar of Johann Ernst Hanxleden S.J. (1681-1732). Universitätsverlag Potsdam, 2013.

Vesdin, Filip (Paulinus a Sancto Bartholomaeo). De antiquitate et affinitate linguæ Zendicæ, Samscrdamicæ, et Germanicæ dissertation. Padua, Typis seminarii, 1798. 
[1] The nature of the relations between "East" and "West" before the late 18th century differs from the later, colonial attitudes, dealt with in Said's works. "Driven by a hunger for expanding trade, the desire to spread the Christian faith, or the wish to establish diplomatic ties, Europeans frequently found themselves at the mercy of East Asian powers. It was not until the middle of the 19th century that Western powers gained some measure of control over their East Asian counterparts, notably in the Chinese Opium Wars and the forced opening of the Japanese market by American gunboats" (Hertel and Keevak 1).

[2] Romaji is one of the four Japanese writing systems and an example of linguistic contact in the history of script - its first version was developed on the basis of the Portuguese script in the mid1650 s and used in Jesuit printed books. Other, more traditional, Japanese scripts are further examples of such contact - the logographic kanji script was introduced around A.D. 400 from China, but in the 8th century Japan started developing two independent indigenous syllabic orthographies - katakana and hiragana. These scripts emerged due to the fact that the Japanese language differs structurally from Chinese - as an agglutinative language, Japanese expresses syntactic relations with suffixes, while Chinese, as an analytic language, uses other means of expression.

[3] Patañjali's comments themselves represent a case of further elaboration, and supplement the older comments of Pāṇini's grammar - Kātyāyana's Vārtika.

[4] For the list of more recent scholars see: Scharf 234. In Croatia Indian linguistic tradition received far more attention than any other Asian linguistic thought, including the writings of Mislav Ježić and Milka Jauk-Pinhak. An important recent contribution to the discussion of Vesdin has been given by Ivan Andrijanić and Petra Matović in "Filip Vesdin and the Comparison of Sanskrit with Iranian and Germanic Languages," Language \& History, 2019, DOI:10.1080/17597536.2019.164985, and by Ivan Andrijanić in "A List of Sanskrit and Latin Cognates in Vesdin's Treatise De Latini Sermonis Origine," Journal of Indo-European Studies, vol. 45, 2017, pp. 195-234. Ines Županov's works also give valuable insights into the missionary linguistics in India during the early modern period. 
[5] Vesdin wrote: Construxit P. Hanxleden Grammaticam linguae Malabaricae, quamvis enim jam ante ipsum plures manuscriptae, a Carmelitis Excalceatis, ejusdem regni Missionariis concinnatae exstarent grammaticae, attamen Hanxlediana correctior, locupletior, et tutior est. [P. Hanxleden has compiled a Grammar of the Malayalam language, although even before him there existed many manuscript grammars produced by the Barefoot Carmelites, missionaries of the same kingdom. Nevertheless, Hanxleden's grammar is more correct, richer and more reliable.] In De manuscriptis codicibus Indicis R. P. Joan. Ernesti Hanxleden epistola ad R. P. Alexium Mariam a S. Joseph carmelitam excalceatum F. Paulinus a S. Bartholomaeo, Carmelita Discalceatus Ling. Orient. Professor, Vienna 1799, p. 4.

[6] Printed in 1796 and translated into several languages: German in 1798 by J. R. Forster, English in 1800 , and French in 1808.

[7] The notion of some relatedness of Sanskrit to other Indo-European languages is actually much older (cf. Van Driem 1047-49). By the end of the 16th century missionaries and traders in India had already noticed some grammatical and lexical interrelatedness of Sanskrit, Latin, and Greek (as attested in letters written by English Jesuit Thomas Stephens and Italian trader Fillipo Sassetti), but the first scholar to propose that the languages of northern India are also members of the "IndoScythian" language family was Claudius Salmasius (1588-1653). The theory of a common IndoEuropean protolanguage, originally produced by Marcus Zuerius van Boxhorn (1612-1653), was almost a century and a half old in Jones's time (Van Driem 1047-49). Jones's lecture in 1786 helped its further propagation: "Because of Jones' stature as a scholar of Persian, his high place in the British colonial government and his role in founding the Asiatic Society, his pronouncement gained him so much fame in and beyond the English-speaking world that he stole the show and for a good many years eclipsed his predecessors in the annals of linguistics" (Van Driem 1049).

\section{c) (†) $\ominus$}

Creative Commons Attribution-NonCommercial-NoDerivatives 4.0 International License 